\title{
Phenytoin-induced Toxicity in the Postnatal Developing Cerebellum of Wistar Rats, Effect of Calotropis procera on Histomorphometric Parameters
}

\author{
Toxicidad Inducida por Fenitoína en el Desarrollo Postnatal del Cerebelo de Ratas \\ Wistar, Efecto de Calotropis procera sobre los Parámetros Histomorfométricos
}

\author{
*,**Imosemi, I.O. \& ${ }^{* *}$ Osinubi, A.A.
}

IMOSEMI, I. O. \& OSINUBI, A. A. Phenytoin-induced toxicity in the postnatal developing cerebellum of Wistar rats, effect of Calotropis procera on histomorphometric parameters. Int. J. Morphol., 29(2):331-338, 2011.

SUMMARY: The role of methanolic leaf extracts of Calotropis procera in phenytoin-induced toxicity on histomorphometric variables in the postnatal developing cerebellum of Wistar rat was studied. Pregnant rats were treated orally with $50 \mathrm{mg} / \mathrm{kg}$ phenytoin in pre and post natal life and $300 \mathrm{mg} / \mathrm{kg}$ methanolic leaf extract of Calotropis procera 1 hour prior to phenytoin administration. $200 \mathrm{mg} / \mathrm{kg}$ vitamin C (standard antioxidant) was also administered orally 1 hour prior to phenytoin treatment. The control animals received water. Standard diet of rat pellets and water were provided ad libitum. At the end of the experiment, the offspring of days 1, 7, 14, 21, 28 and 50 post partum, five per group were sacrificed by cervical dislocation. The cerebellum of all groups were dissected out and processed for histomorphometric studies. The results showed in the developing cerebellum of phenytoin treated animals, a delayed cell maturation in the external granular layer, reduction of the molecular layer, astrocytic gliosis and loss of Purkinje cells on day 50 postpartum. Administration of extracts of Calotropis procera and vitamin $\mathrm{C}$ though reversed these changes when compared with the phenytoin treated group, but not significantly when compared with the control. In conclusion, supplementation with methanolic extracts of Calotropis procera reduced the rate at which phenytoin induced toxicity in the postnatal developing cerebellum of Wistar rat.

KEY WORDS: Phenytoin; Toxicity; Cerebellar development; Calotropis procera.

\section{INTRODUCTION}

Phenytoin (diphenylhydantoin or dilantoin) is a commonly used drug for all types of epilepsy except absence seizures and its cerebrospinal fluid concentrations equals that of the unbound fraction in the plasma (McNamara, 1996). The developing central nervous system (CNS) in the neonatal period has been found to be more vulnerable to the neurotoxic effects of phenytoin because of the higher brain concentration of phenytoin (Kaneko et al., 1988). Prenatal exposure to phenytoin may result in a spectrum of structural, developmental and behavioural changes known as fetal hydantoin syndrome (Nanda et al., 1989). The mechanism of phenytoin teratogenicity is still being investigated but some researchers reported that phenytoin teratogenicity may be induced by embryonic hypoxia with vascular disruption and tissue necrosis as a result of ischaemic damage and or reacting oxygen specie (ROS) generation at reoxygenation (Danielsson et al., 1997), and that epoxide intermediates or other toxic metabolites of phenytoin are postulated to bind to DNA, RNA and proteins in mouse fetuses. This binding may be associated with an increased teratogenic action of phenytoin (Kaneko \& Kondo, 1995).

The cerebellum plays a major role in controlling various motor activities in the body. It is a highly organized structure, in which the Purkinje cells (Pc) are the sole output of the cerebellar cortex (Altman, 1972), and it is one of the first structures of the brain to differentiate, however, it achieves its mature configuration many months after birth (Bouët et $a l ., 2005)$. For this reason, the cerebellum is especially vulnerable to developmental irregularities (Kern \& Jones, 2006).

* Department of Anatomy, College of Medicine, University of Ibadan, Ibadan, Nigeria.

** Department of Anatomy, College of Medicine, Lagos State University, Ojoo, Lagos, Nigeria. 
Vitamin C, a standard antioxidant functions in the body by readily donating electron to regenerate other antioxidants, such as vitamin E and GSH (Halpner et al., 1998), and can inhibit ROS generation and lipid peroxidation by chelating free transition metals such as copper and iron (Zablocka \& Janusz, 2008).

Calotropis procera also known as the giant milk weed is one of the flowering plants commonly found in the tropics world over. The plant is found in almost all parts of Nigeria but more abundantly in the Northern part of the country (Ghazanfar, 1989). It derived its common name, giant milk weed, from the thick white sap which oozes from a cut stem or from the stem when a leaf is plucked off. Hence, the family to which the plant belongs is referred to as milkweed family (Sofowora, 1984). The medicinal effect of Calotropis procera has been demonstrated as a remedy for black scars of face, boils, cold cough, asthma, ear ache, eczema, skin eruptions and inflammatory lesions, body pains, rheumatoid arthritis, syphilis, leprosy and oedema (Misra and Fridowich, 1972). The antioxidant activity of Calotropis procera which is thought to scavenge the oxygen free radicals have also been documented (Rao \& Dubey, 1990).

The objective of this research was to test the hypothesis that Calotropis procera could protect or reduce the rate at which phenytoin induced toxicity on histomorphometric parameters in postnatal developing cerebellum of Wistar rat.

\section{MATERIAL AND METHOD}

Breeding of Animals. Forty sexually matured female rats weighing about $160 \mathrm{~g}$ of Wistar strain were obtained from the central animal house of the Faculty of Basic Medical Sciences, University of Ibadan, Ibadan, Oyo State. The animals were randomly divided into five groups of eight animals per group. They were mated and pregnancy confirmed by the presence of vaginal plug. The animals were fed with standard diet of rat pellets and water provided $a d$ libitum. All procedures on animal handling conformed to the acceptable guidelines on the ethical use of animals in research.

Drug Preparation and Administration. The experimental animals received phenytoin, vitamin $\mathrm{C}$ (standard antioxidant) and Calotropis procera leaf extracts separately and in combination, while the control animals received water.

Phenytoin dissolved in tap was administered orally in pre and postnatal life in the dose of $50 \mathrm{mg} / \mathrm{kg}$. Sodium salt of Phenytoin (capsule) manufactured by Man care Pharmaceuticals PVT Ltd. India purchased from the pharmacy, University College Hospital (UCH), Ibadan was used for the experiment. $200 \mathrm{mg} / \mathrm{kg}$ body weight vitamin $\mathrm{C}$ was administered one hour orally prior to phenytoin administration, to the experimental animals in pre and post natal life.

Extraction of Calotropis Procera leaves. The leaves of Calotropis procera were harvested within the main campus of the University of Ibadan and authenticated by Dr. O.A. Ugbogu of the Forestry Research Institute of Nigeria (FRIN), Ibadan with a Forestry Harberium Identification number (FHI) 108221. They were air-dried at room temperature for two and a half months, blended and made into powdered form of about $1.2 \mathrm{~kg}$. Cold methanolic extraction for about 72 hours to facilitate better extraction of flavonoids was done. The methanolic solution was concentrated with rotatory evaporator at a temperature below $50^{\circ} \mathrm{C}$ for 7 hours. The concentrated extract $(187.0 \mathrm{~g})$ was stored in the refrigerator until use. The concentrated extract was reconstituted with water before administration.

Phytochemical studies of the leaves of Calotropis procera was done in the Department of Pharmacognosy, Faculty of Pharmacy, University of Ibadan, Ibadan. The following compounds were screened for, alkaloids, flavonoids, cardenolides, saponins and tannins.

$300 \mathrm{mg} / \mathrm{kg}$ body weight methanolic extract of Calotropis procera was administered one hour orally prior to phenytoin administration, to the experimental animals in pre and post natal life. The dose of Calotropis procera extracts used in the research was based on a safety evaluation study carried out by Mossa et al., (1991) that the use of the extract in a single high doses (up to $3 \mathrm{~g} / \mathrm{kg}$ body weight) does not produce any visible toxic symptoms or mortality.

\section{Grouping of animals}

Group I: Control group received water

Group II: Received 50mg/kg phenytoin

Group III: Received 300mg/kg Calotropis procera

Group IV: Received Calotropis procera + phenytoin

Group V: Received phenytoin $+200 \mathrm{mg} / \mathrm{kg}$ Vitamin C

At the end of the experiment, the animals of days 1 , $7,14,21,28$ and 50 postpartum, five per group were weighed and killed. The brain was dissected out and the cerebellum removed and fixed in $10 \%$ formol saline. The cerebellar tissues were processed employing routine paraffin embedding technique and stained in Haematoxylin and $\operatorname{Eosin}(\mathrm{H}$ and $\mathrm{E})$ for histomorphometric studies. 
Histomorphometric Studies: The following histological and histomorphometric parameters were studied;

i. Histomorphometric studies including, thickness of the external granular and molecular layers of the cerebellar cortex using a graticule (calibrated eye piece attached to the microscope), and

ii. Purkinje cell density using a graticule (calibrated eye piece attached to the microscope measuring $1.3 \mathrm{~mm}$ in length). Counting was done per unit area of the graticule space as described by Blinkov \& Gleezer (1968). A total of five separate equidistant area of graticule space was counted for each slide.

Statistical Analysis. The data obtained was further analyzed with unpaired student t-test using computer software, Microsoft Excel. The Mean, Standard Deviation, SD, and the level of significance at $95 \%$ Confidence Interval calculated.
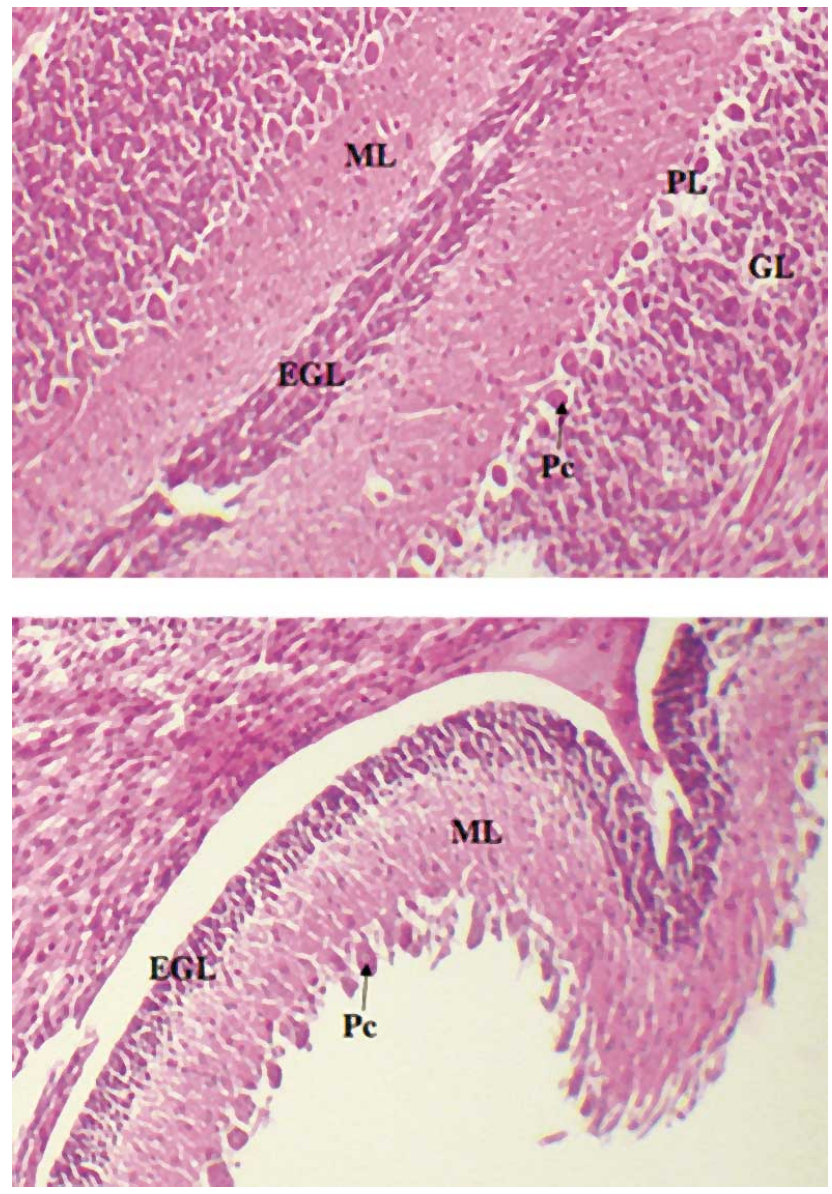

Fig. 1. Photomicrographs of the day 14 old postpartum rat cerebellar cortex of a) control group with reduced EGL, and (b) phenytointreated group showing thicker EGL. Molecular layer, ML, Purkinje layer, PL, Granular layer, GL, H \& E X100.

\section{RESULTS}

Phytochemistry. Phytochemical studies carried out on the leaves of Calotropis procera showed that it contained mainly flavonoids, alkaloids and some cardenolides.

\section{Histomorphometric Studies}

Thickness of the external granular layer (EGL):A significantly thicker EGL was seen in phenytoin treated group on day 14 postpartum, $\mathrm{P}<0.05(0.04 \pm 0.01 \mathrm{~mm}$ vs $0.03 \pm 0.01 \mathrm{~mm}$ ) (Table I, Fig. 1). A reduction in the EGL thickness was observed on day 14 postpartum when Calotropis procera extracts and vitamin $\mathrm{C}$ were administered to the phenytoin-treated animals (Table I, Fig. 2).

Table I. Mean thickness of the external granular layer (EGL) in the control and treated groups on days 1, 7 and 14 postpartum.

\begin{tabular}{lccc}
\hline Days/Gp & $\mathbf{1}$ & $\mathbf{7}$ & $\mathbf{1 4}$ \\
\hline Control & $0.04 \pm 0.01$ & $0.05 \pm 0.01$ & $0.03 \pm 0.01$ \\
Pheny & $0.03 \pm 0.01$ & $0.04 \pm 0.01$ & $0.04 \pm 0.01^{\mathrm{a}}$ \\
$C p$ & $0.04 \pm 0.01$ & $0.05 \pm 0.01$ & $0.03 \pm 0.01$ \\
Pheny+Cp & $0.04 \pm 0.01$ & $0.04 \pm 0.01$ & $0.03 \pm 0.01^{\mathrm{d}}$ \\
Pheny+vC & $0.04 \pm 0.01$ & $0.05 \pm 0.01$ & $0.02 \pm 0.01^{\mathrm{e}}$ \\
\hline
\end{tabular}

Thickness of the molecular layer (ML): There was a reduction of the molecular (ML) thickness in the phenytointreated animals on days 1, 7, 14, 28 and 50, but significantly on days 14 and 28, $\mathrm{P}<0.05$. Vitamin $\mathrm{C}$ administered to phenytoin-treated animals significantly improved the ML thickness on days 14,28 and 50 postpartum, $\mathrm{P}<0.05$ $(0.07 \pm 0.02 \mathrm{~mm}$ vs $0.05 \pm 0.01 \mathrm{~mm}, 0.22 \pm 0.02 \mathrm{~mm}$ vs $0.16 \pm 0.03 \mathrm{~mm}$ and $0.22 \pm 0.04 \mathrm{~mm}$ vs $0.16 \pm 0.02 \mathrm{~mm}$ respectively). Calotropis procera extracts administered to phenytoin-treated group significantly improved the ML thickness on day 14 postpartum, $\mathrm{P}<0.05(0.13 \pm 0.02 \mathrm{~mm}$ vs $0.05 \pm 0.01 \mathrm{~mm}$ ). The ML thickness was significantly reduced in the vitamin $\mathrm{C}$ plus phenytoin-treated group compared with extracts of Calotropis procera on day 14 postpartum, $\mathrm{P}<0.05$ (Table II). The astrocytes, observed by mere optical observation were heavily gliosed on day 50 postpartum in the ML of phenytoin-treated group compared to the moderately gliosed astrocytes in the control, vitamin C and Calotropis procera group (Fig. 3).

Purkinje cell density (Pc): A loss of Purkinje cells (Pc) was seen in phenytoin-treated group on days 14, 28 and 50 but significantly on day 50 postpartum when compared with the control group, $\mathrm{P}<0.05$ (34.6 \pm 4.0 vs $41.2 \pm 3.3$ ) 

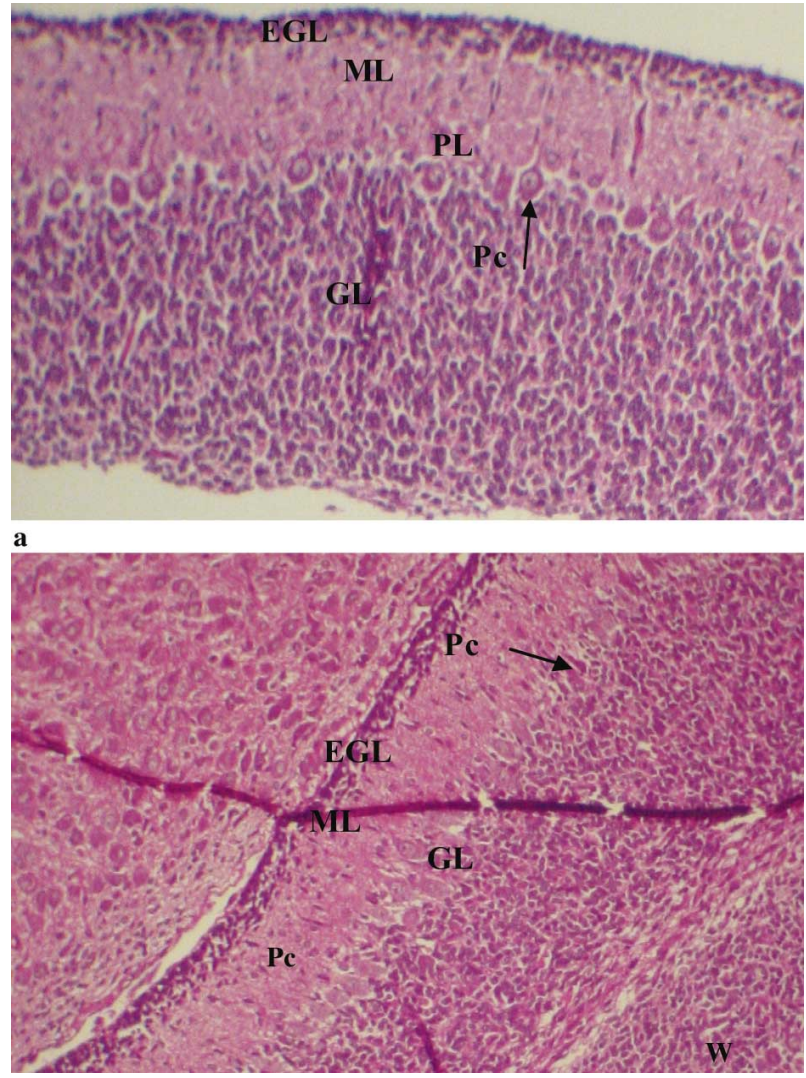

Fig. 2. Photomicrograph of the day 14 old postpartum rat cerebellar cortex of a) phenytoin + vitamin $\mathrm{C}$ treated group and b) phenytoin + Calotropis procera extracts-treated group showing a reduced external granular layer (EGL) thickness. Molecular layer, ML, Purkinje layer, PL, Granular layer, GL, Purkinje cells, Pc. H \& E X100

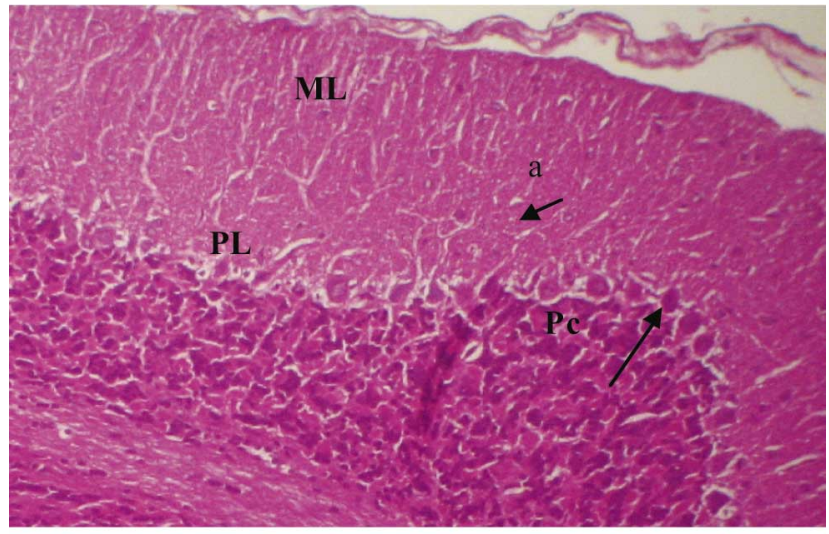

a

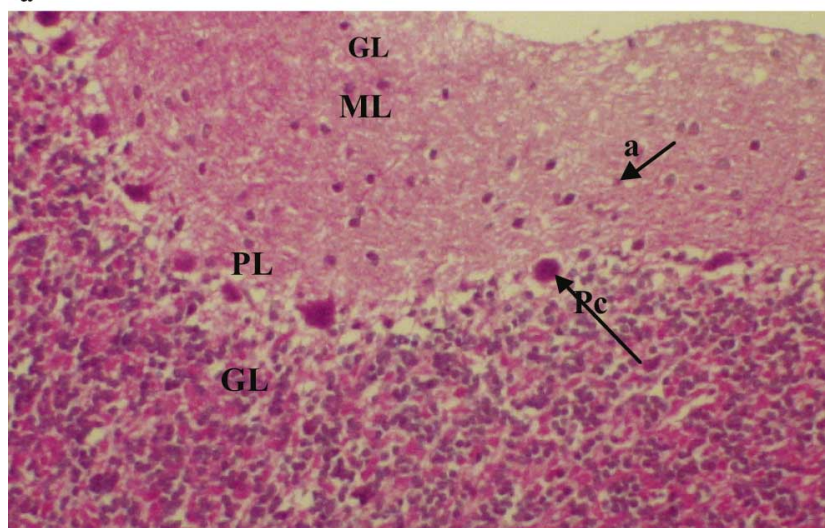

Fig. 3. Photomicrographs of the day 50 old postpartum rat cerebellar cortex of a) control group with increased Pc density and (b) phenytoin-treated group showing loss of Purkinje cells, Purkinje cells. Molecular layer, ML, Purkinje layer, PL, Granular layer, GL. Astrocyte, a. H \& E X100.

Table II. Mean thickness of the molecular layer (ML) in the control and phenytoin treated groups on days 1 , $7,14,21,28$ and 50 postpartum.

\begin{tabular}{lcccccc}
\hline Days/Gp & $\mathbf{1}$ & $\mathbf{7}$ & $\mathbf{1 4}$ & $\mathbf{2 1}$ & $\mathbf{2 8}$ & $\mathbf{5 0}$ \\
\hline Control & $0.02 \pm 0.01$ & $0.03 \pm 0.01$ & $0.14 \pm 0.02$ & $0.19 \pm 0.02$ & $0.20 \pm 0.03$ & $0.19 \pm 0.02$ \\
Pheny & $0.02 \pm 0.01$ & $0.02 \pm 0.01$ & $0.05 \pm 0.01 \mathrm{c}$ & $0.20 \pm 0.03$ & $0.16 \pm 0.03 \mathrm{a}$ & $0.16 \pm 0.02$ \\
Pheny+vC & $0.03 \pm 0.01$ & $0.03 \pm 0.00$ & $0.07 \pm 0.02 \mathrm{c}^{\mathrm{dh}}$ & $0.20 \pm 0.02$ & $0.22 \pm 0.02 \mathrm{e}$ & $0.22 \pm 0.04 \mathrm{~d}$ \\
$C p$ & $0.02 \pm 0.01$ & $0.02 \pm 0.01$ & $0.13 \pm 0.02^{\mathrm{f}}$ & $0.18 \pm 0.01$ & $0.20 \pm 0.02$ & $0.19 \pm 0.02$ \\
Pheny+Cp & $0.02 \pm 0.01$ & $0.03 \pm 0.01$ & $0.13 \pm 0.02^{\mathrm{f}}$ & $0.19 \pm 0.02$ & $0.20 \pm 0.01$ & $0.19 \pm 0.02$ \\
\hline
\end{tabular}

(Table III, Fig. 3). Extracts of Calotropis procera and vitamin $\mathrm{C}$ administered to phenytoin-treated animals improved the depletion of Purkinje cells (Table III, Fig. 4).

Table III. Mean density of the Purkinje cells $(\mathrm{Pc})$ in the control and treated groups on days $14,21,28$ and 50 postpartum.

\begin{tabular}{lcccc}
\hline Days/Gp & $\mathbf{1 4}$ & $\mathbf{2 1}$ & $\mathbf{2 8}$ & $\mathbf{5 0}$ \\
\hline Control & $63.4 \pm 4.2$ & $49.6 \pm 4.0$ & $37.4 \pm 9.2$ & $41.2 \pm 3.3$ \\
Pheny & $58.6 \pm 8.0$ & $48.4 \pm 4.2$ & $37.6 \pm 8.4$ & $34.6 \pm 4.0 \mathrm{a}$ \\
$C p$ & $60.4 \pm 6.0$ & $48.8 \pm 3.3$ & $39.0 \pm 3.6$ & $37.8 \pm 7.9$ \\
Pheny+Cp & $62.4 \pm 6.6$ & $48.8 \pm 3.6$ & $39.6 \pm 8.6$ & $39.6 \pm 7.1$ \\
Pheny+vC & $61.4 \pm 8.0$ & $47.6 \pm 3.0$ & $40.0 \pm 6.6$ & $36.4 \pm 6.4$ \\
\hline
\end{tabular}




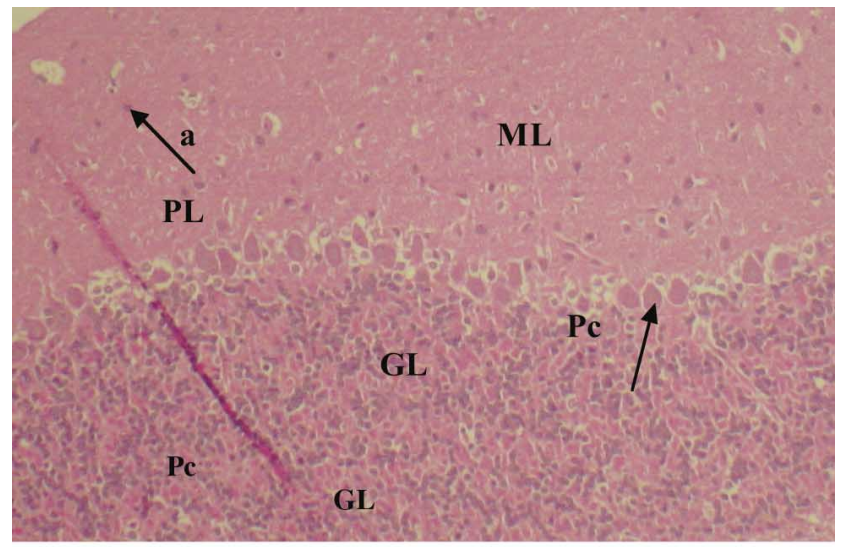

a

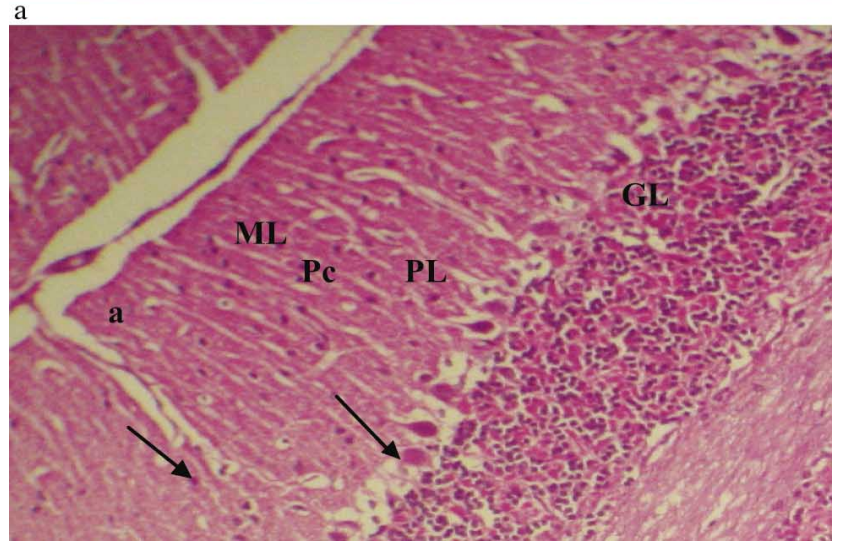

Fig. 4. Photomicrographs of the day 50 old postpartum rat cerebellar cortex of a) phenytoin + vitamin $\mathrm{C}$ group and (b) phenytoin+Calotropis procera treated group showing increased Purkinje cell, Pc, density. Molecular layer, ML, Purkinje layer, PL, Granular layer, GL. Astrocyte, a. H \& E X100.

\section{DISCUSSION}

The cerebellum, like the entire nervous system, is known to be affected substances such as nutritional deficiency (Clark et al., 1973), cyanide (Malomo et al., 2004; Pavlakovic et al., 1994), irradiation (Sugihara et al., 2000), alcohol (West et al., 1990), and anticonvulsant drugs, such as valproic acid, carbamazine, phenytoin and phenobarbital (Szot et al., 1985).

The association of phenytoin with approximately two-three fold increase in the malformations in neonates exposed to phenytoin has been documented (Janz, 1982). Pontocerebellar hypoplasia has been shown in some children of women who were managed with phenytoin during pregnancy (Gadisseaux et al., 1984). Squire et al. (1990) reported a case of cerebellar malformation in a neonate with absence of Purkinje cells in any part of the cerebellar hemispheres with accompanied hypoplastic cerebellum and extensive gliosis. Phenytoin has been found to induce neurotoxicity by generating free radicals resulting in oxidative stress which leads to cellular damage and dysfunction (Liu et al., 1997).

The present postnatal study was carried out to investigate the role of methanolic extracts of Calotropis procera and vitamin $\mathrm{C}$ in the in vivo model of phenytoininduced toxicity in rats, by assessing the histomorphometric changes in the developing cerebellum of Wistar rat.

The external granular layer (EGL) is the most metabolically active part of the developing cerebellum as the differentiation of the cells of this layer gives rise to the outer stellate, basket, granule and Golgi type II cells of the cerebellar cortex. This differentiation process requires energy. In this study, a thicker EGL in phenytoin treated animals during the late weanling phase (day 14 postpartum) suggested delayed maturation of the cells. The mechanism for the delay is not completely clear, but intrauterine hypoxia/ ischaemia, embryo-foetal toxicity and vascular necrosis of phenytoin administration is well documented (Wells \& Winn, 1996). Also, phenytoin can be enzymatically bioactivated to a reactive intermediate leading to increased formation of ROS, which can damage essential macromolecules, including DNA. A delayed maturation of cells was found by Bhattacharya \& Rao (1997) to be due to DNA damage. Ohmori et al. (1992) reported a wide EGL containing pyknotic cells, reduction in cerebellar weight, together with retardation of motor and behavioural development.

The thinner EGL observed when extracts of Calotropis procera and vitamin C were administered probably enhanced the metabolic activities in the EGL and inhibiting phenytoin toxicity by oxidizing it as well as increasing the survival of glial cells possibly by directly scavenging reactive oxygen species and indirectly augmenting their antioxidant capacity.

The molecular layer (ML) is situated between the EGL and Purkinje layer (PL). It becomes the most superficial layer after the complete disappearance of the EGL on day 20 post partum in rats (Jacobson, 1991; Hatten \& Heintz, 1995). The ML is packed with dendrites and axons but has relatively few neurons. Only two of the neuron types (basket and outer stellate) have their cell bodies in the ML (West, 1995). The thickness of the ML is therefore determined by the amount of cells and fibres present (Rakic \& Sidman, 1970), but majorly by accretion of new parallel fibres (Rakic, 1971). In this study phenytoin administered during the post weanling growth phase together with gestation and lactation carry over effect (accumulation of phenytoin) may lead to 
reduction in astrocyte population (astrocytic gliosis). Phenytoin administration significantly reduced the thickness of the ML implying that it adversely affected the fibres and the few neurons present as well as the glial cell population may cause spatial learning deficits in later life. Neuronal death in the granule layer or delayed parallel fibre formation caused by delayed granule cell maturation could have affected the density of the unmyelinated parallel fibres in the ML and hence the reduction in the ML thickness. Adams \& Duchen (1992) found in cryptogenic epilepsy (where recurrent hypoxia is likely) that the astrocytes become heavily gliosed contributing to the reduction in ML thickness.

The Purkinje cell is one of the largest and most complex neurons in the mammalian nervous system (Miyakawa et al., 1992). The Purkinje cell axons are the only efferent from the cerebellar cortex and are highly vulnerable to ischaemia (Graham, 1992). In this study, the significant loss of Purkinje cells found in the post weaning animals induced by phenytoin may be due to its intrauterine hypoxia in the developing cerebellum. Kern \& Jones reported using animal models that the Purkinje cells are vulnerable to ischaemia, hypoxia, and excitotoxicity. The depletion of Purkinje cells corroborated previous studies that phenytoin administration within the first three weeks of postnatal life caused immature dendritic development of Purkinje cells and impaired selective aspects of motor coordination ability (Ohmori et al., 1999). Extracts of Calotropis procera and vitamin $\mathrm{C}$ improved the Purkinje cell density probably by their free radical scavenging property. The free radical scavenging property of Calotropis procera may be one of the mechanisms by which the drug is effective as a traditional medicine.

In conclusion, the present study has shown that phenytoin administered to animals in pre and postnatal life exerted neurotoxic effects evidenced by delayed maturation of cells of the EGL, reduction of the ML thickness, reduction in astrocyte and Purkinje cell population and that administration of extracts of Calotropis procera and vitamin $\mathrm{C}$ reduced the rate at which phenytoin toxicity occurred in the postnatal developing cerebellum of Wistar rat.

IMOSEMI, I. O. \& OSINUBI, A. A. Toxicidad inducida por fenitoína en el desarrollo postnatal del cerebelo de ratas Wistar, efecto de Calotropis procera sobre los parámetros histomorfométricos. Int. J. Morphol., 29(2):331-338, 2011.

RESUMEN: Fue estudiado el rol de los extractos metanólicos de las hojas de Calotropis procera en la toxicidad inducida por fenitoína sobre las variables histomorfométricas en el desarrollo postnatal del cerebelo de ratas Wistar. Ratas preñadas fueron tratadas por vía oral con $50 \mathrm{mg} / \mathrm{kg}$ de fenitoína durante la vida pre y post natal. Además, fue administrado, por vía oral, una hora antes del tratamiento con fenitoína $300 \mathrm{mg} / \mathrm{kg}$ de extracto metanólico de las hojas de Calotropis procera y $200 \mathrm{mg} / \mathrm{kg}$ de vitamina C (antioxidante estándar). Los animales control recibieron agua. Una dieta estándar de pellets para rata y agua se proporcionaron ad libitum. Al final del experimento, 5 crías por grupo de 1, 7, 14, 21, 28 y 50 días post parto, fueron sacrificadas por dislocación cervical. El cerebelo de todos los animales de los diferentes grupos fueron disecados y procesados para el estudio histomorfométrico. Los resultados mostraron en el desarrollo del cerebelo de los animales tratados con fenitoína un retraso en la maduración de células en la capa granular externa, reducción de la capa molecular, gliosis astrocitaria y pérdida de las células de Purkinje en el día 50 post parto. La administración de extractos de Calotropis procera y vitamina C, aunque invirtieron estos cambios, en comparación con los grupos tratados con fenitoína, no fueron significativos en comparación con el control. En conclusión, la suplementación con extractos metanólicos de Calotropis procera redujo la velocidad a la que la fenitoína induce toxicidad en el desarrollo postnatal del cerebelo de ratas Wistar.

PALABRAS CLAVE: Fenitoína; Toxicidad; Desarrollo del cerebelo; Calotropis procera.

\section{REFERENCES}

Adams, J.H. \& Duchen, L.W. Greenfield's Neuropathology. $5^{\text {th }}$ Ed. New York, Oxford University Press, 1992. pp. 1009 .

Altman, J. Postnatal development of the cerebellar cortex in rat II. Phases in the maturation of Purkinje cells and the molecular layer. J. Comp. Neurol., 145:399-463, 1972.

Bhattacharya, R. \& Rao, R. V. Cyanide induced DNA fragmentation in mammalian cell cultures. Toxicology, 123(3):207-15, 1997.
Blinkov, S. M. \& Glezer, H. The human brain in figures and tables: a quantitative hand book. New York, Plenum Press and basic books, 1968. pp. 334-8.

Bouët, V.; Dijk, F.; Ijkema-Paassen, J.; Wubbles, R. J.; Want, J. J. \& Gramsbergen, A. Early hypergravity exposure effects calbindin-D28k and inositol-3-phosphate expression in Purkinje cells. Neurosci. Lett., 382(1-2):10$5,2005$.

Clark, G. M.; Zamenhof, S.; Van Mathers, E.; Grauel, L. \& 
Krugger, L. The effect of prenatal malnutrition on dimensions of cerebral cortex. Brain Res., 54:397-402, 1973.

Danielsson, B. R.; Azarbayjani, F.; Sköld, A. C. \& Webster, W. S. Initiation of phenytoin teratogenesis: Pharmacologically induced embryonic bradycardia and arrhythmia resulting in hypoxia and possible free radical damage at reoxygenation. Teratology, 56(4):271-81, 1997.

Gadisseaux, J. F.; Rodrigues, J. \& Lyon, G. Pontoneocerebellar hypoplasia--a probable consequence of prenatal destruction of the pontine nuclei and a possible role of phenytoin intoxication. Clin. Neuropathol., 3(4):160-7, 1984.

Ghazanfar, S. A. Savana plants. An illustrated guide. London, Macmillian publishers Ltd., 1989. pp.115-8.

Graham, D. I. Hypoxia and vascular disorders. In: Greenfield's neuropathology. Adams, J. H. \& Cuchen, L. W. (eds). London, Arnolds, 1992. pp.153-268.

Halpner, A.; Handelman, G.; Belmont, C.; Harris, J. \& Blumberg, J. Protection by vitamin C of oxidant induced loss of vitamin E in rat hepatocytes. J. Nutr. Biochem., 9:355-9, 1998.

Hatten, M. E. \& Heintz, N. Mechanisms of neural patterning and specification in the developing cerebellum. Аппи. Res. Neurosci., 18:385-408, 1995.

Jacobson, M. Histogenesis and morphogenesis of cortical structures. Developmental Neurobiology. $3^{\text {rd }}$ Ed. New York, Plenum Press, 1991. pp.401-51.

Janz, D. On major malformations and minor anomalies in the offspring of parents with epilepsy. In Epilepsy, pregnancy and the child. New York, Plenium Press, 1982. pp. 211-22.

Kaneko, S. \& Kondo, T. Antiepileptic agents and birth defects incidence. Mechanisms and prevention. CNS drugs. 3:41-5, 1995 .

Kaneko, S.; Otani, K.; Fukushima, Y.; Ogawa, Y.; Nomura, Y.; Ono, T.; Nakane, Y.; Teranishi, T. \& Goto, M. Teratogenicity of antiepileptic drugs: Analysis of possible risk factors. Epilepsia, 29:459-67, 1988.

Kern, J. K. \& Jones, A. M. Evidence of toxicity, oxidative stress, and neuronal insult in Autism. J. toxicol. Environ. Health B. Crit. Rev., 9:485-99, 2006.
Liu, C. S.; Wu, H. M.; Kao, S. H. \& Wei, Y. H. Phenytoinmediated oxidative stress in serum of female epileptics: a possible pathogensis in the foetal hydantoin syndrome. Hum. Exp. Toxicol., 16(3):177-81, 1997.

Malomo, A. O.; Imosemi, I. O.; Osuagwu, F. C.; Oladejo, O. W.; Akang, E. E. U. \& Shokunbi, M. T. Histomorphometric studies on the effect of cyanide consumption on the developing cerebellum of Wistar rat (Rattus Novegicus). W. Afr. J. Med., 23(4):323-8, 2004.

McNamara, J. O. Hydantoins. In Goodman and Gilman's Pharmacological Basis of Therapeutics. 9th edition. New York, Pergamon Press, 1996. pp.468-71.

Misra, H. \& Fridowich, I. The role of super oxide anion in the auto oxidation of epinephrine and a simple assay for super oxide dismutase. J. Biol. Chem., 247:3170-85, 1972.

Miyakawa, H.; Lev-Ram, V.; Lasser-Ross, N. \& Ross, W. N. Calcium transients evoked by climbing fibre synaptic inputs in guinea pig cerebellar Purkinje neurons. $J$. Neurophysiol., 68:1178-89, 1992.

Mossa, J. S.; Tariq, M.; Mohsin, A.: Ageel, A. M.; Al-Yahya, M. A.; Al-said, M. S. \& Fatatullah, S. Pharmacological Studies of aerial parts of Calotropics procera. Am. J. Clin. Med., 19(3-4):223-31, 1991.

Nanda, A.; Kaur, S.; Bhakoo, O. N.; Kapoor, M. M. \& Kanwar, A. J. Foetal hydantoin syndrome: a case report. Pediatr. Dermatol., 6:130-3, 1989.

Ohmori, H.; Kobayashi, T. \& Yasuda, M. Neurotoxicity of phenytoin administered to newborn mice on developing cerebellum. Neurotoxicol. Teratol., 14:159-65, 1992.

Ohmori, H.; Ogura, H.; Yasuda, M.; Nakamura, S.; Hatta, T.; Michikawa, T.; Yamashita, K. \& Mikoshiba, K. Developmental Neurotoxicity of phenytoin on granule and Purkinje cells in mouse cerebellum. J. Neurochem., 72(4):1497-506, 1999.

Pavlakovic, G.; Rathinavelu, A. \& Isom, G. E. MK-801 prevents cyanide-induced changes of Fos levels in rat brain. Neurochem. Res., 19(10):1289-94, 1994.

Rakic, P. Neuron-glia relationship during granule cell migration in developing cerebellar cortex: A Golgi and electromicroscopic study in Macacus Rhesus. J. Comp. Neur., 141:283-312, 1971. 
IMOSEMI, I. O. \& OSINUBI, A. A. Phenytoin-induced toxicity in the postnatal developing cerebellum of Wistar rats, effect of Calotropis procera on histomorphometric parameters. Int. J. Morphol., 29(2):331-338, 2011

Rakic, P. \& Sidman, R. L. Histogenesis of cortical layers in human cerebellum particularly the lamina dissecans. $J$. Comp. Neurol., 139:473, 1970.

Rao, M. V. \& Dubey, P. S. Biochemical aspects (antioxidants) for development of tolerance in plants growing at different low levels of ambient air pollutants. Environ. Pollut., 64(1):55-66, 1990.

Sofowora, A. Medicinal plants and traditional medicine in Africa. Ibadan, John Willey and Sons, 1984. pp.142-6.

Squire, W.; Hope, P. L. \& Lindenbaum, R. H. Noecerebellar hypoplasia in a neonate following intra-uterine exposure to anticonvulsants. Dev. Med. Child. Neurol., 31:73742, 1990 .

Sugihara, I.; Bailly, Y. \& Mariami, J. Olivecerebellar climbing fibres in the granuloprival cerebellum: Morphological studies on individual axonal projections in the X-irradiated rat. J. Neuroscience, 20(10):309-12, 2000 .

Szot, P.; Dodson, R. A. \& Johnson, W. E. Effects of certain CNS depressants and verapamil on cGMP in the cerebellum of rats. Res. Commun. Chem. Pathol. Pharmacol., 50(2):309-12, 1985.

Wells, P. G. \& Winn, L. M. Biochemical toxicology of chemical teratogenesis. Crit. Rev. Biochem. Mol. Biol., 31:1-40, 1996.

West, J. R. The cerebellum: In. Neuroscience in Medicine. Conn, P. M. (Ed.). Philadelphia, Lippincott company, 1995. pp.213-25.

West, J. R.; Goodlett, C. R.; Bonthius, D. J.; Hamre, K. M. \& Marcussen, B. L. Cell population depletion associated with fetal alcohol brain damage: mechanisms of BACdependent cell loss. Alcohol Clin. Exp. Res., 14(6):8138, 1990.

Zablocka, A. \& Janusz, M. The two faces of reacting oxygen species. Postepy. Hig. Med. Dosw., 62:118-24, 2008.
Correspondence to:

Imosemi, I. O.

Department of Anatomy

College of Medicine

University of Ibadan

Ibadan - Nigeria

Phone: +234-7068025958.

Email: innosemi@yahoo.co.uk

Received: 04-08-2010

Accepted: 26-12-2010 